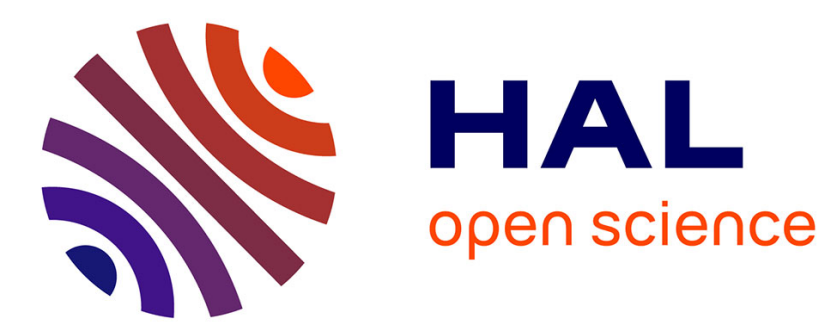

\title{
n ITO/p InP : a photo and electroluminescent diode
}

L. Gouskov, H. Luquet, C. Gril, A. Oemry, M. Savelli

\section{To cite this version:}

L. Gouskov, H. Luquet, C. Gril, A. Oemry, M. Savelli. n ITO/p InP : a photo and electroluminescent diode. Revue de Physique Appliquée, 1982, 17 (3), pp.125-132. 10.1051/rphysap:01982001703012500 . jpa-00244980

\section{HAL Id: jpa-00244980 https://hal.science/jpa-00244980}

Submitted on 1 Jan 1982

HAL is a multi-disciplinary open access archive for the deposit and dissemination of scientific research documents, whether they are published or not. The documents may come from teaching and research institutions in France or abroad, or from public or private research centers.
L'archive ouverte pluridisciplinaire HAL, est destinée au dépôt et à la diffusion de documents scientifiques de niveau recherche, publiés ou non, émanant des établissements d'enseignement et de recherche français ou étrangers, des laboratoires publics ou privés. 


\title{
n ITO/p InP : a photo and electroluminescent diode $\left(^{*}\right)$
}

\author{
L. Gouskov, H. Luquet, C. Gril, A. Oemry and M. Savelli \\ Groupe d'Etudes des Matériaux, Composants et Systèmes, Centre d'Etudes d'Electronique des Solides $\left({ }^{* *}\right)$, \\ Université des Sciences et Techniques du Languedoc, 34060 Montpellier Cedex, France
}

(Reçu le 23 septembre 1981, révisé le 13 novembre 1981, accepté le 23 novembre 1981)

\begin{abstract}
Résumé. - Des diodes ITO/lnP ont été fabriquées en déposant une couche d'ITO par pulvérisation chimique réactive sur un substrat monocristallin d'InP de type $\mathrm{p}$. Ces diodes sont à la fois photodétectrices et électroluminescentes. Les résultats des caractérisations électriques et l'étude de l'interface suggèrent que ces diodes sont des homojonctions enterrées. Le rendement quantique maximum atteint 0,9 . L'électroluminescence est due à la recombinaison sur les accepteurs dans InP p, la puissance lumineuse émise à $1,34 \mathrm{eV}$ pour un courant continu de $100 \mathrm{~mA}$ est de $0,67 \mathrm{~mW}$.
\end{abstract}

\begin{abstract}
ITO/InP photodetectors and electroluminescent diodes have been fabricated spraying a ITO layer onto a single crystal $\mathrm{p}$ InP. The results of electrical and interface characterizations agree with a model of a buried homojunction. The maximum quantum efficiency reaches 0.9 . The electroluminescence is correlated to the recombination on the acceptors in the $\mathrm{p} \mathrm{InP,} \mathrm{the} \mathrm{emitted} \mathrm{light} \mathrm{at} 1.34 \mathrm{eV}$ for a direct current of $0.1 \mathrm{~A}$ is $0.67 \mathrm{~mW}$.
\end{abstract}

1. Introduction. - InP has recently received increased attention for use in microwave field effect transistors, infrared lasers and solar cells. The Schottky type diodes on $\mathrm{n}$ InP, used as gates in FETs show a low barrier height and a large leakage current $[1,2]$. A great improvement of this type of device has been obtained inserting a very thin oxide layer between the metal and the semiconductor substrate $[3,4]$. Very good MIS Schottky diodes have been recently fabricated by Kamimura [5] on $p$ InP, the barrier height reached $1.12 \mathrm{eV}$ while it was only $0.83 \mathrm{eV}$ on equivalent devices involving $\mathbf{n}$ InP. It has also been reported by Hokelek [6] that the barrier height of true Pd Schottky diode was higher on p-type InP when the opposite was observed for Schottky GaAs or Si diodes. In the solar energy conversion field, various devices have been investigated. The best efficiencies $\eta \sim 15 \%$ (AM2) were obtained from epitaxial $n$ CdS/p InP cells [7] and also from sputtered ITO/p InP cells [8]. Three models have been proposed to explain such a high efficiency : the heterojunction type structure with a very low interface states density for epitaxial $\mathbf{n ~ C d S / p}$ InP diodes, the SIS type structure for ITO/p InP diodes [9] or the buried homojunction structure [10].

(*) Communication présentée à l'ESSDERC, 1981.

(**) Associé au C.N.R.S.

REVUE DE PHYSIQUE APPLIQUÉE. - T. 17, N' 3, MARS 1982
The MIS Schottky diodes on $p$ InP [5] showed a conversion efficiency as high as $14.5 \%$ under AM2 which is almost the same as the $15 \%$ conversion efficiency (AM1) obtained by Turner [11] on $n^{+} / p$ InP homojunction diodes.

This paper is a contribution to the fabrication of a both photo and electroluminescent diode involving p-type InP and ITO (Indium Tin Oxide) transparent window. The very simple spray technology used to deposite the ITO layer is described and the electrooptical properties of the obtained devices are presented.

2. Fabrication method. - The p InP substrates were polished single crystal wafers, (111) or (100) oriented, of $\mathrm{Zn}$ doped InP pulled by the LEC method (Metal Research). The $300 \mathrm{~K}$ density and mobility of holes were respectively $p_{0}=10^{16} \mathrm{~cm}^{-3}, \mu_{\mathrm{p}}=$ $50 \mathrm{~cm}^{2} / V$.s. An ohmic back contact was first provided with a $4 \% \mathrm{Au}-\mathrm{Zn}$ alloy diffused $2 \mathrm{~min}$ at $470{ }^{\circ} \mathrm{C}$ under $\mathrm{H}_{2}$ atmosphere. The front surface was chemically etched in $1 \% \mathrm{Br}$-methanol and rinsed in methanol prior to the ITO deposition. The ITO layer (about $0.5 \mu \mathrm{m}$ thick) was grown using the liquid phase hydrolysis of $\mathrm{SnCl}_{4}$ and $\mathrm{InCl}_{3}$ on the InP warmed substrates ( $T$ spray $\sim 400^{\circ} \mathrm{C}$ ) at a deposition rate of $0.15 \mu \mathrm{m} / \mathrm{min}$ under a $\mathrm{N}_{2}$ flux. This method is described in [12]. Electrical contacts were supplied to the diode using silver paint. Figure 1 presents the front and back 


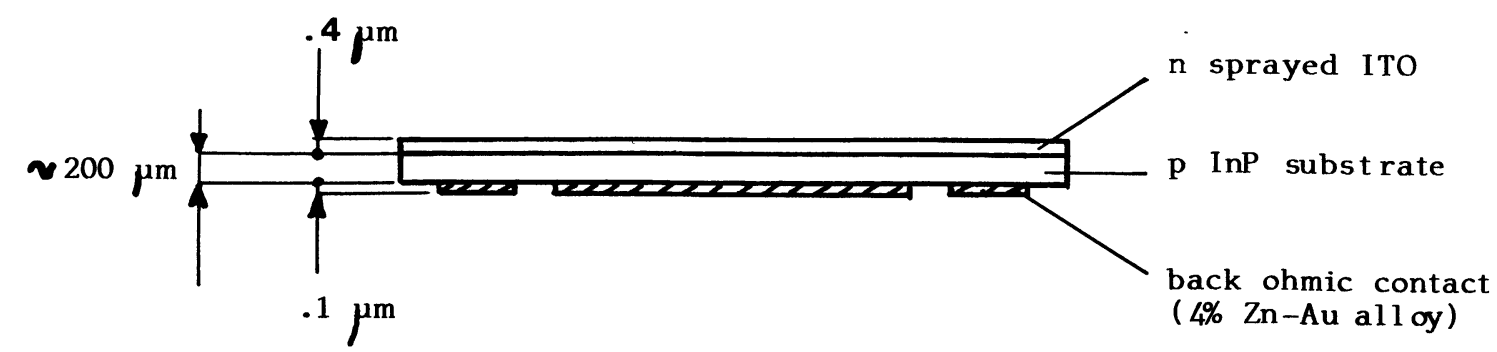

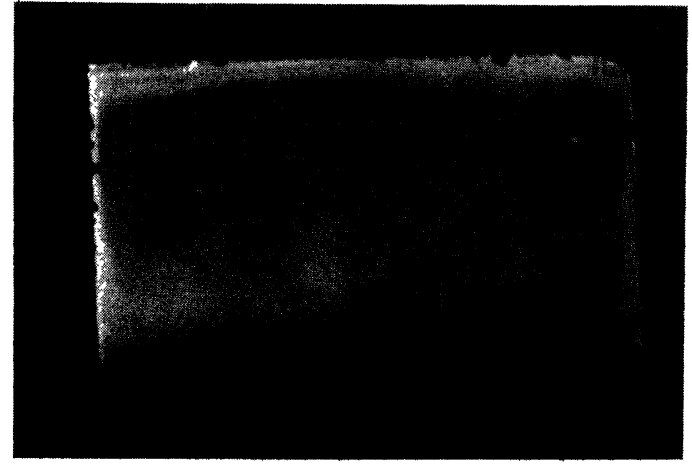

Diode front face

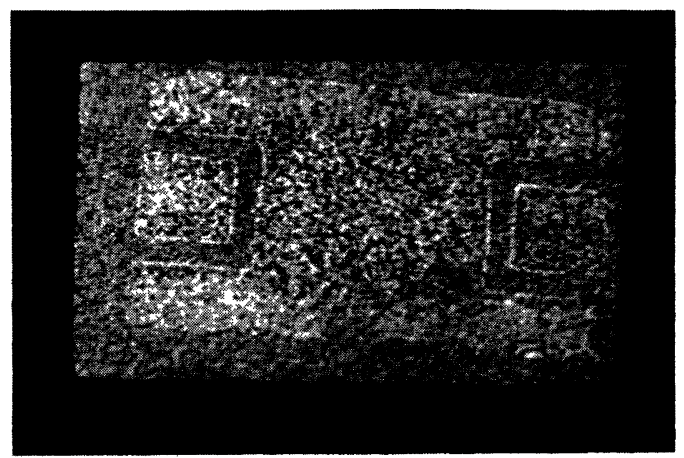

Diode back face

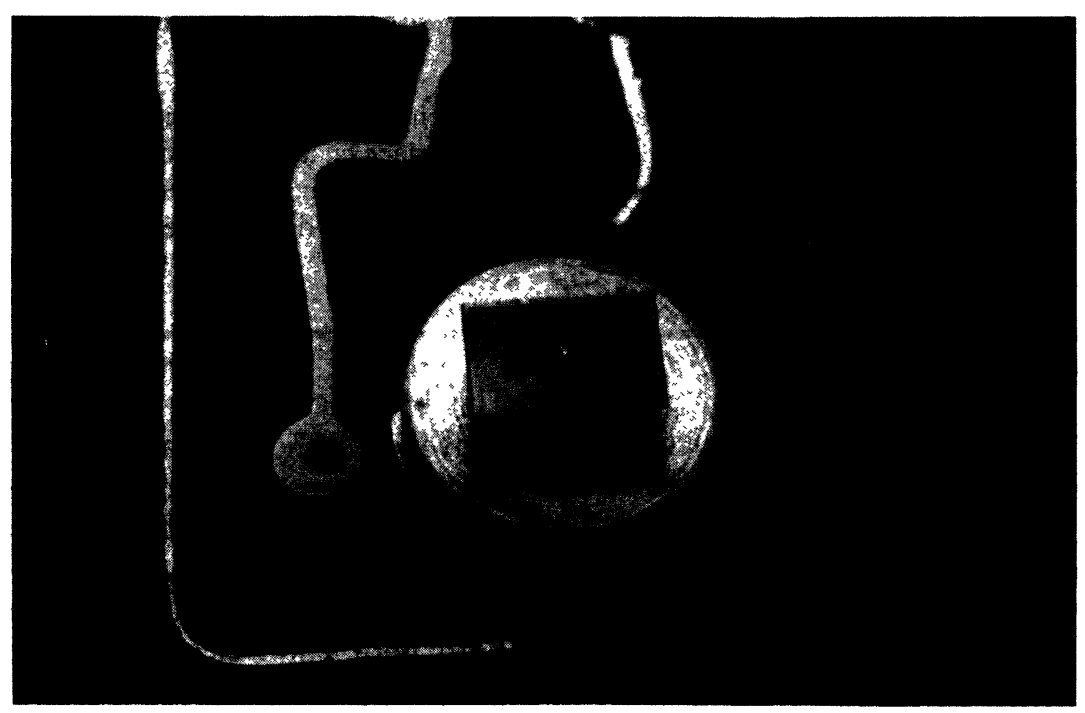

Diode lay out

Fig. 1. - Diode description, dimensions $6 \times 4 \times 0.2 \mathrm{~mm}^{3}$.

aspects of the diodes. The main fabrication parameters are the spray temperature and the Sn content of the starting solution of $\mathrm{SnCl}_{4}$ and $\mathrm{InCl}_{3}$. In a recent paper [13] it has been shown that for an atomic ratio $\mathrm{Sn} / \mathrm{In}=C_{\mathrm{Sn}}=10 \%$, the optimized spray temperature was $4500^{\circ} \mathrm{C}$, leading to a $11 \%$ solar conversion efficiency (AM1). The optimization of the fabrication has been pursued with the study of the influence of $C_{\mathrm{Sn}}$ on diode properties. The results of this study are presented in this paper.

3. Interface investigation. - It has already been reported that EBIC (Electron Beam Induced Current) profile measurements indicate that the junction is not localized at the ITO/InP interface but is deeper into
InP at about $1 \mu \mathrm{m}$ from this interface. For another $C_{\mathrm{Sn}}\left(C_{\mathrm{Sn}}=1 \%\right)$ this result is still valid and figure $2 a$ shows the EBIC and SEC (Secondary Electrons Current) observed on $\mathrm{Zn} 10$ diode. The record of the EBIC signal is shown on figure $2 b$. This record is not exactly the same for every choosen scanning line. The diffusion length value seems depth dependent : $\sim 1 \mu \mathrm{m}$ near the junction, greater $\sim 5 \mu \mathrm{m}$ into the substrate. This result suggests that the structure of the device is a buried $\mathrm{n} / \mathrm{p}$ homojunction, as it was admitted for sputtered ITO/p InP solar cells [10]. In the sputtered diodes, the n-type layer formation was attributed to the mechanical damages induced by sputtering. For our sprayed diodes, the n-type layer formation could be induced by some diffusion process. Sn is a 


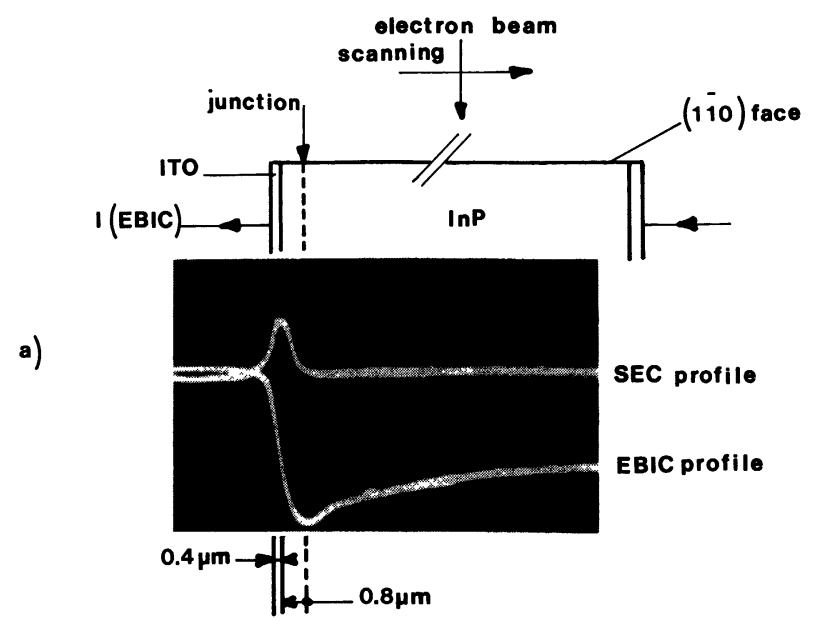

b)

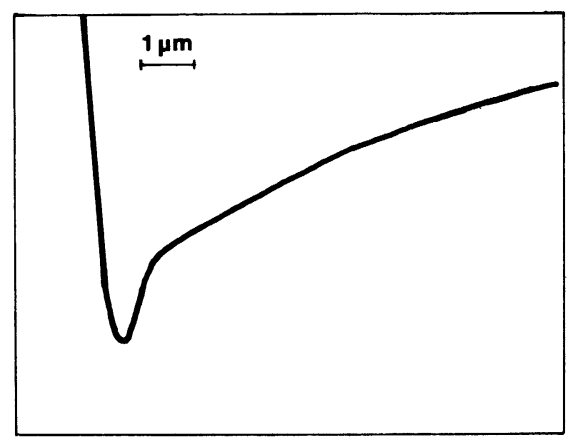

Fig. 2. - a) EBIC and SEC profiles on $\mathrm{Zn} 10$ diode, electron energy : $20 \mathrm{keV}$. b) EBIC profile showing the existence of two diffusion lengths.

donor when it is substituted to In into $\operatorname{InP}$, then $\mathrm{Sn}$ diffusion could give an n-type layer.

Ion probe analysis results of sputtered ITO/InP diodes have been published by Bachmann et al. [14]. It is shown that in the heat treated diodes involving ITO and not pure $\operatorname{In}_{2} \mathrm{O}_{3}$, Sn penetrates into the InP at about $0.4 \mu \mathrm{m}$ (for a $250{ }^{\circ} \mathrm{C}$ heat treatment) and at a doping level greater than $5 \times 10^{17} \mathrm{~cm}^{-3}$. The poor sensitivity of our ion probe measurements

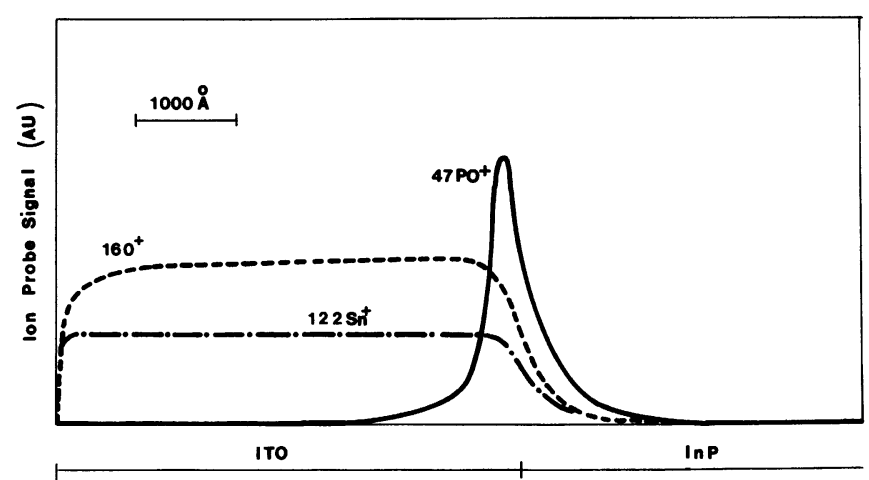

Fig. 3. - Ion probe analysis : $\mathrm{O}^{+}, \mathrm{PO}^{+}, \mathrm{Sn}^{+}$profiles. $I=30 \mathrm{nA}$ (argon). $\left(\sim 10^{18} \mathrm{~cm}^{-3}\right.$ ) has not allowed to detect a Sn or $\mathrm{O}$ doping level into InP but has shown the presence of $\mathrm{P}-\mathrm{O}$ bonds at the interface. Figure 3 shows the three profiles corresponding to $m / e=16\left(\mathrm{O}^{+}\right)$, $m / e=47\left(\mathrm{PO}^{+}\right)$and $m / e=122\left(\mathrm{Sn}^{+}\right)$signals. It will be seen later that when pure $\operatorname{In}_{2} \mathrm{O}_{3}$ is involved, the obtained device is less efficient. This leads to think that $\mathrm{Sn}$ diffusion play an important role in diode formation but is not the only process responsible for the obtained device and that the presence of an oxide layer cannot be disregarded.

4. Dark direct $I-V$ characteristics. - The analysis of the dark $I-V$ characteristics versus temperature allows generally to define the transport model in the investigated junction. In a preceding paper [13], it has been shown that in the diodes for which $C_{\mathrm{Sn}}=10 \%, 265<T_{\mathrm{sp}}<465^{\circ} \mathrm{C}$, in the high direct current range $\left(I>10^{-5} \mathrm{~A} / \mathrm{cm}^{2}\right)$ and for $T>210 \mathrm{~K}$, the current obeyed the law

$$
I=I_{0}\left(\mathrm{e}^{q\left(V-R_{s} I\right) / n k T}-1\right)+V / R_{\mathrm{sh}},
$$

$I_{0}$ : saturation current, $q$ : electronic charge, $n$ : ideality coefficient, $k$ : Boltzmann constant, $R_{\mathrm{s}}$ : serie resistance, $R_{\mathrm{sh}}$ : shunt resistance. The $I_{0}$ current was temperature dependent $: I_{0}=I_{00} \mathrm{e}^{-\Delta E / k T}$ with $\Delta E \sim 800 \mathrm{meV}$ and $1<n \leqslant 2$. These values of $n$ and $\Delta E$ led to the conclusion that the transport in these diodes was nearly well explained by generation-recombination in the space charge of an homojunction.

The dark direct characteristics have here been studied for a set of diodes in which $C_{\mathrm{Sn}}$ was varied between $0 \%$ and $160 \%$. Two spray temperatures : $T_{\text {sp }}=400$ and $450^{\circ} \mathrm{C}$ and two ITO thicknesses : $d=0.082 \mu \mathrm{m}$ and $0.4 \mu \mathrm{m}$ have been considered. Figure 4 gives an example of the $I-V$ characteristics for the $\mathrm{Zn} 10$ diode $\left(C_{\mathrm{sn}}=1 \%, T_{\mathrm{sp}}=450{ }^{\circ} \mathrm{C}\right.$, $d=0.4 \mu \mathrm{m}$ ). Below $213 \mathrm{~K}$, the $I-V$ curves are complicated and no longer obey the simple exponential law, they will not be interpreted here. The diodes involving pure $\mathrm{In}_{2} \mathrm{O}_{3}$ and $0.4 \mu \mathrm{m}$ thick ITO layers and the diodes with $C_{\mathrm{Sn}}=1 \%$ and $0.082 \mu \mathrm{m}$ thick ITO layers show an ideality coefficient $n>2$. In this case the injection or generation-recombination model are not convenient to describe the transport and tunnelling is probably dominant, $I-V$ characteristic is then better described by the law $I=I_{0}^{\prime} \mathrm{e}^{a V}, I_{0}^{\prime}=I_{00}^{\prime} \mathrm{e}^{\beta T}$.

Figure $5 a$ presents the $I_{0}$ variation versus $10^{3} / T$ for the $\mathrm{Zn} 10$ diode and figure $5 b$ the $I_{0}^{\prime}$ variation versus $T$ for the $\mathrm{Zn} 3$ diode.

Figure 6 shows the variations of the parameters $n, I_{0}$ at $300 \mathrm{~K}$ versus $C_{\mathrm{Sn}}$ for $T_{\mathrm{sp}}=400{ }^{\circ} \mathrm{C}$ and $T_{\mathrm{sp}}=450^{\circ} \mathrm{C}$ (for $C_{\mathrm{Sn}}=1 \%$ only). This study shows that the electrical properties of the diodes are related to the $\mathrm{Sn}$ diffusion : the $0 \% \mathrm{Sn}$ content leads to a device in which tunnelling is dominant whereas diodes involving ITO show generation-recombination transport. In the same way the devices involving a thin ITO 


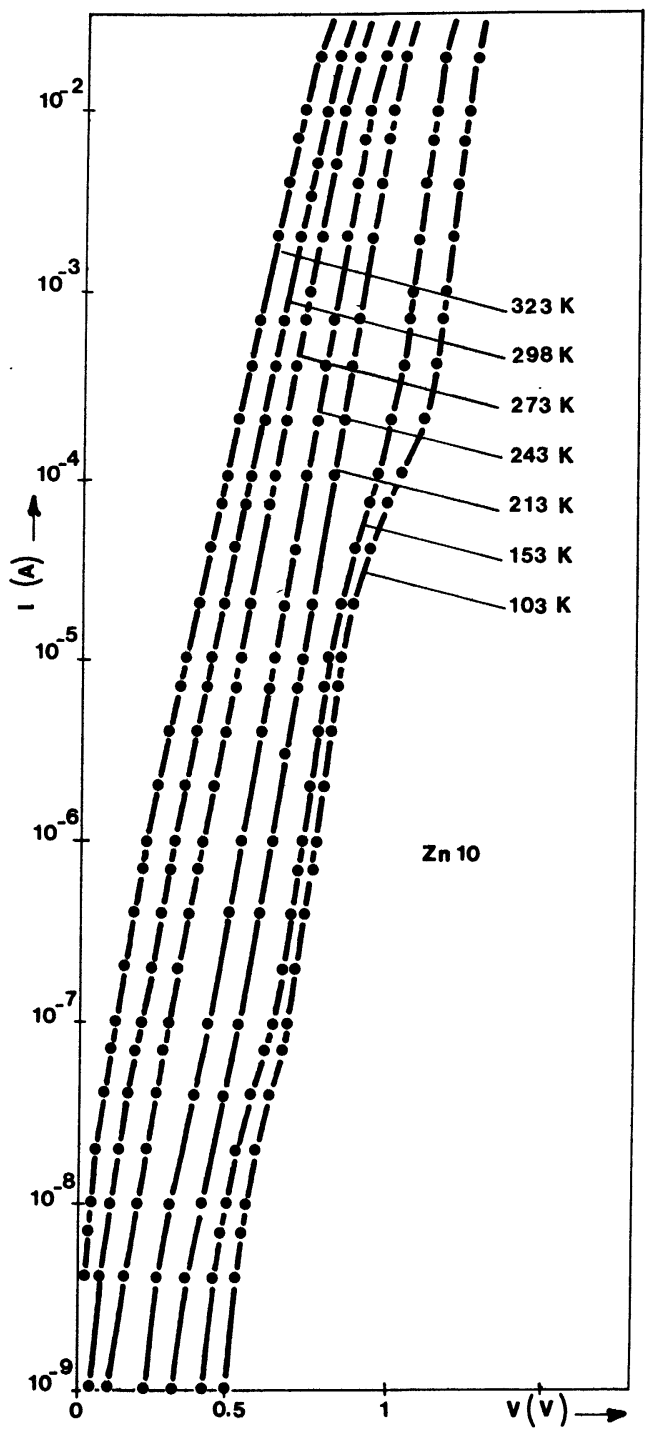

Fig. 4. - Dark direct $I-V$ characteristics versus temperature, $\mathrm{Zn} 10$ diode $\left(C_{\mathrm{Sn}}=1 \%, T_{\mathrm{sp}}=450^{\circ} \mathrm{C}, d_{\mathrm{ITO}}=0.41 \mu \mathrm{m}\right.$, $S=17.2 \mathrm{~mm}^{2}$ )

Fig. 5. - Saturation current versus temperature : a) $\mathrm{Zn} 10$ diode $\left(C_{\mathrm{Sn}}=1 \%, T\right.$ spray $=450{ }^{\circ} \mathrm{C}, d_{\mathrm{ITo}} 0.41 \mu \mathrm{m}$, $S=17.2 \mathrm{~mm}^{2}$ )

$$
\begin{aligned}
I & =I_{0} \mathrm{e}^{q V / n k T}, \quad I_{0}=I_{00} \mathrm{e}^{-\Delta E / k T} ; \\
I_{00} & =3.5 \times 10^{3} \mathrm{~A} ; \\
\Delta E & =0.703 \mathrm{~V} ; \\
n & \sim 2 .
\end{aligned}
$$

b) $\mathrm{Zn} 3$ diode $\left(C_{\mathrm{sn}}=1 \%, T\right.$ spray $=450^{\circ} \mathrm{C}, d_{\mathrm{ITO}}=0.082 \mu \mathrm{m}$, $S=15 \mathrm{~mm}^{2}$ ):

$$
\begin{aligned}
I & =I_{0}^{\prime} \mathrm{e}^{a V}, \quad I_{0}^{\prime}=I_{00}^{\prime} \mathrm{e}^{\beta \mathrm{T}} ; \\
I_{00}^{\prime} & =2.5 \times 10^{-19} \mathrm{~A} ; \\
a & =15.3 \mathrm{~V}^{-1} ; \\
\beta & =8.5 \times 10^{-2} \mathrm{~K}^{-1} .
\end{aligned}
$$

layer, that is to say a short diffusion time leads also to a tunnel device. However no strong discontinuity is observed between pure $\operatorname{In}_{2} \mathrm{O}_{3} / \mathrm{InP}$ devices and ITO/InP devices. This fact suggests that $\mathrm{Sn}$ diffusion is not the only process which rules the diode formation.

5. Electrical properties under illumination. - The ability of these diodes to work as photodetectors or solar cells depends on their electrical properties under illumination. The main parameters of a photodetector are its responsitivity (photocurrent per light power) and its signal to noise ratio (the noise depends on both
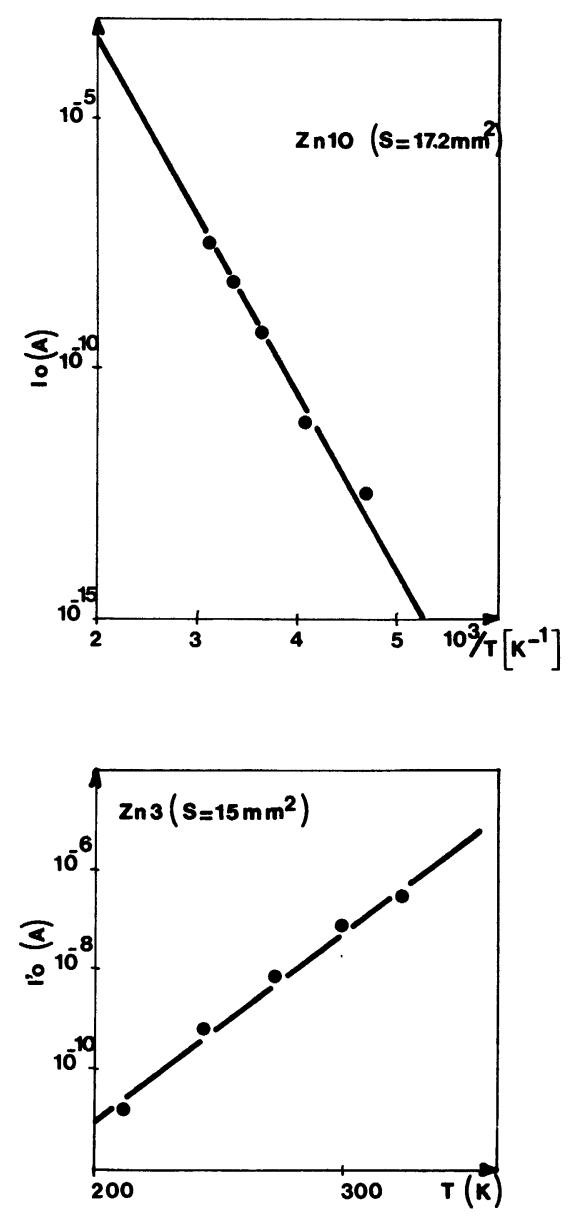


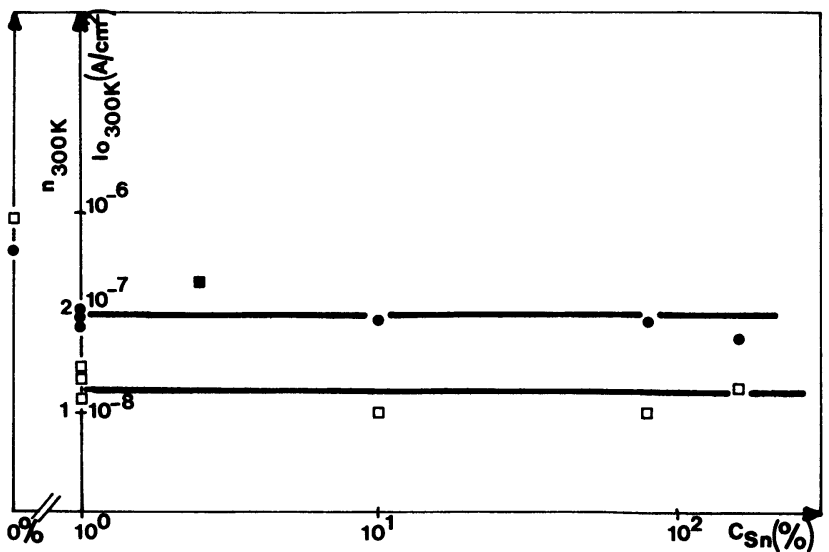

Fig. 6. - Variations of ideality coefficient $n: \bullet$ and $I_{0}$ at $300 \mathrm{~K}: \square$ versus the Sn content in ITO $\left(C_{\mathrm{Sn}}\right)$ for a spray temperature $T_{\mathrm{sp}}=400{ }^{\circ} \mathrm{C}$. For $C_{\mathrm{sn}}=1 \%$, Tspray was $450^{\circ} \mathrm{C}$, three samples were studied.

the photocurrent and the dark current. For a solar cell the efficiency $\eta$ depends on the short circuit photocurrent created by the integrated solar spectrum : $I_{\mathrm{sc}}$, the photovoltage $V_{\mathrm{oc}}$ and on the power losses in the serie and shunt resistances.

5.1 I- $V$ CHARACTERISTICS UNDER SOLAR ILLUMINATION AM1. - Figure 7 shows the $I-V$ characteristic under solar illumination AM1 $(100 \mathrm{~mW})$ for the best diode $(\mathrm{Zn} \mathrm{10)}$. The solar conversion efficiency $\eta$ reaches $14 \%$. The $V_{\mathrm{oc}}$ and $I_{\mathrm{sc}}$ variations versus $C_{\mathrm{Sn}}$ are presented on figure $8, V_{\mathrm{oc}}$ appears quite independent of $C_{\mathrm{Sn}}$ while $I_{\mathrm{sc}}$ shows a weak variation versus this para-

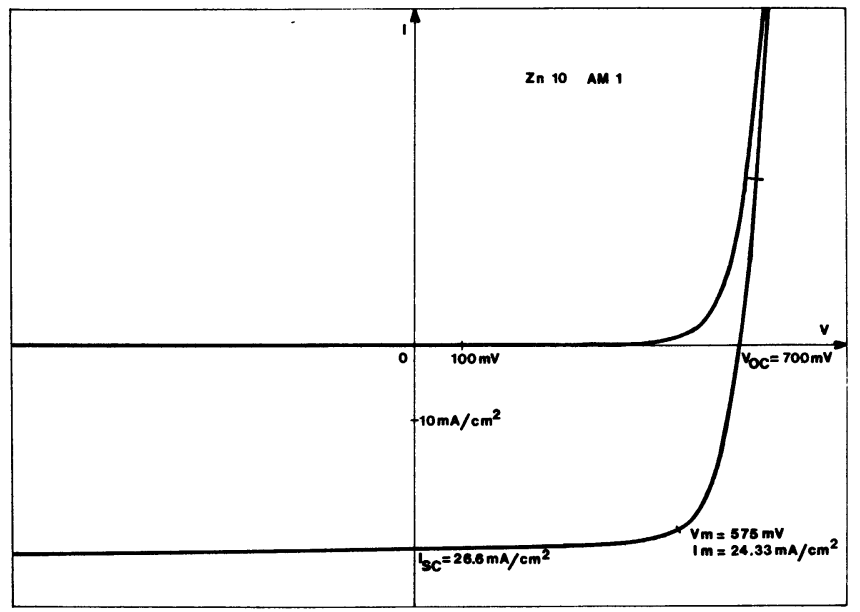

Fig. 7. - I-V characteristic under solar illumination AM1 for the $\mathrm{Zn} 10$ diode at $300 \mathrm{~K}$ :

$$
\begin{aligned}
& \quad I_{\mathrm{sc}}=26.6 \mathrm{~mA} / \mathrm{cm}^{2} ; \\
& V_{\mathrm{oc}}=700 \mathrm{mV} ; \\
& \quad \eta=14 \% ; \\
& \text { fill factor }=0.75 ; \\
& \text { Total } S=17.2 \mathrm{~mm}^{2} ; \\
& \text { Illuminated } S=16.5 \mathrm{~mm}^{2} .
\end{aligned}
$$

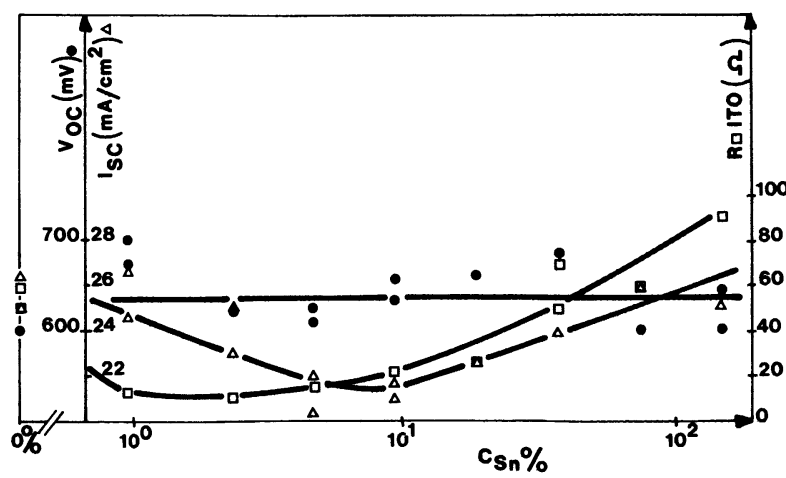

Fig. 8. $-V_{\mathrm{oc}}: \bullet, I_{\mathrm{sc}}: \triangle$ and $R \square$ ITO : $\square$ versus Sn content (illumination AM1, $T=300 \mathrm{~K}$ ).

meter. It has been verified that the fill factor of our solar cells depends mainly on the back contact resistance. The Au-Zn contacts on this low doped p InP are difficult to reproduce, they are ohmic but sometimes resistive. The fill factor depends also on the ITO layer resistance. Figure 8 shows also the measured ITO square resistance $R \square$. The $C_{\mathrm{Sn}}$ variation of $R \square$ is rather flat between 1 and $10 \%$, it increases for $C_{\mathrm{Sn}}<1 \%$ and $C_{\mathrm{Sn}}>10 \%$. The minimum resistivity of our sprayed ITO is about $5 \times 10^{-4} \Omega \mathrm{cm}$. The examination of this figure 8 shows that the best solar cell efficiency occurs for $C_{\mathrm{Sn}} \sim 1 \%$.

$5.2 I_{\mathrm{sc}}$ SPECTRUM. - Figure 9 presents the spectrum analysis of the quantum efficiency $\eta_{\mathrm{q}}$ for the $\mathrm{Zn} 10$ diode, that is to say the ratio $I_{\mathrm{sc}} / q F$ where $F$ is the photon flux. This spectrum shows the steep variation of $\eta_{\mathrm{q}}$ at the band edge of InP, the rather flat aspect of the spectrum in the range $1.35-3 \mathrm{eV}$. The $\eta_{\mathrm{q}}$ decrease due to the ITO gap starts at about $3 \mathrm{eV}$. The interferences are due to the ITO layer. This spectrum allows to define the responsitivity of this diode used as a photodetector. It varies between $0.57 \mathrm{~A} / \mathrm{W}$ at $1.40 \mathrm{eV}$ and $0.26 \mathrm{~A} / \mathrm{W}$ at $3 \mathrm{eV}$.

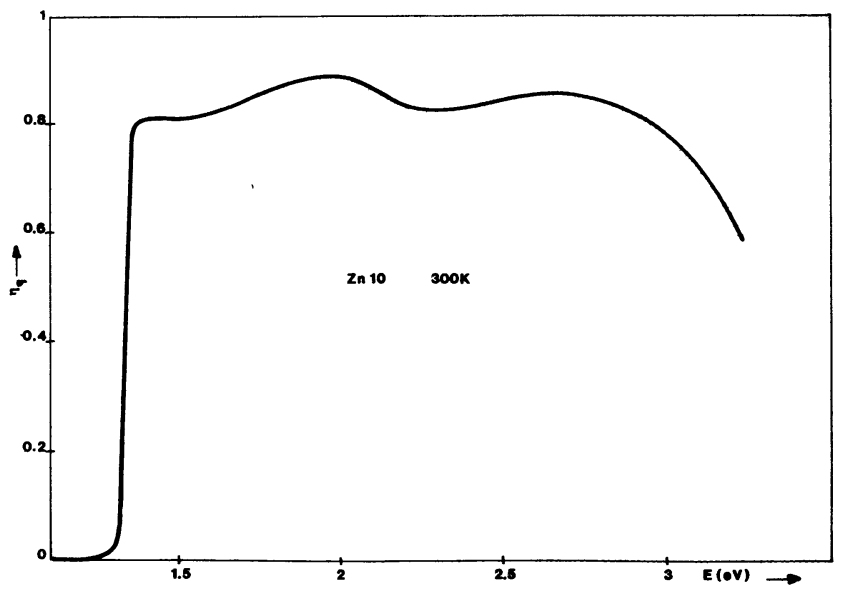

Fig. 9. - Quantum efficiency spectrum : $\eta_{\mathrm{q}}$ of the $\mathrm{Zn} 10$ diode. 


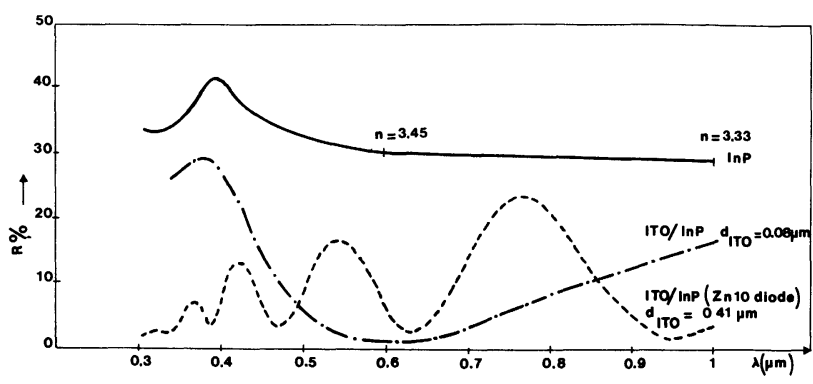

Fig. 10. - Measured reflectivity of sprayed ITO/p InP diodes compared to InP reflectivity.

Figure 10 shows the reflection losses measured on the $\mathrm{Zn} 10$ diode $\left(d_{\text {ITO }}=0.41 \mu \mathrm{m}\right)$ and on a diode for which $d_{\text {ITo }}=0.082 \mu \mathrm{m}$ ). If these two spectra are compared to the pure InP reflection spectrum, it is evident that ITO behaves as a good antireflection coating and that the mean $R$ value on the whole spectrum range decreases from $R=30 \%$ for InP to $R \sim 12 \%$ for ITO/p InP. This figure emphasizes the interest of this device and of its simple fabrication

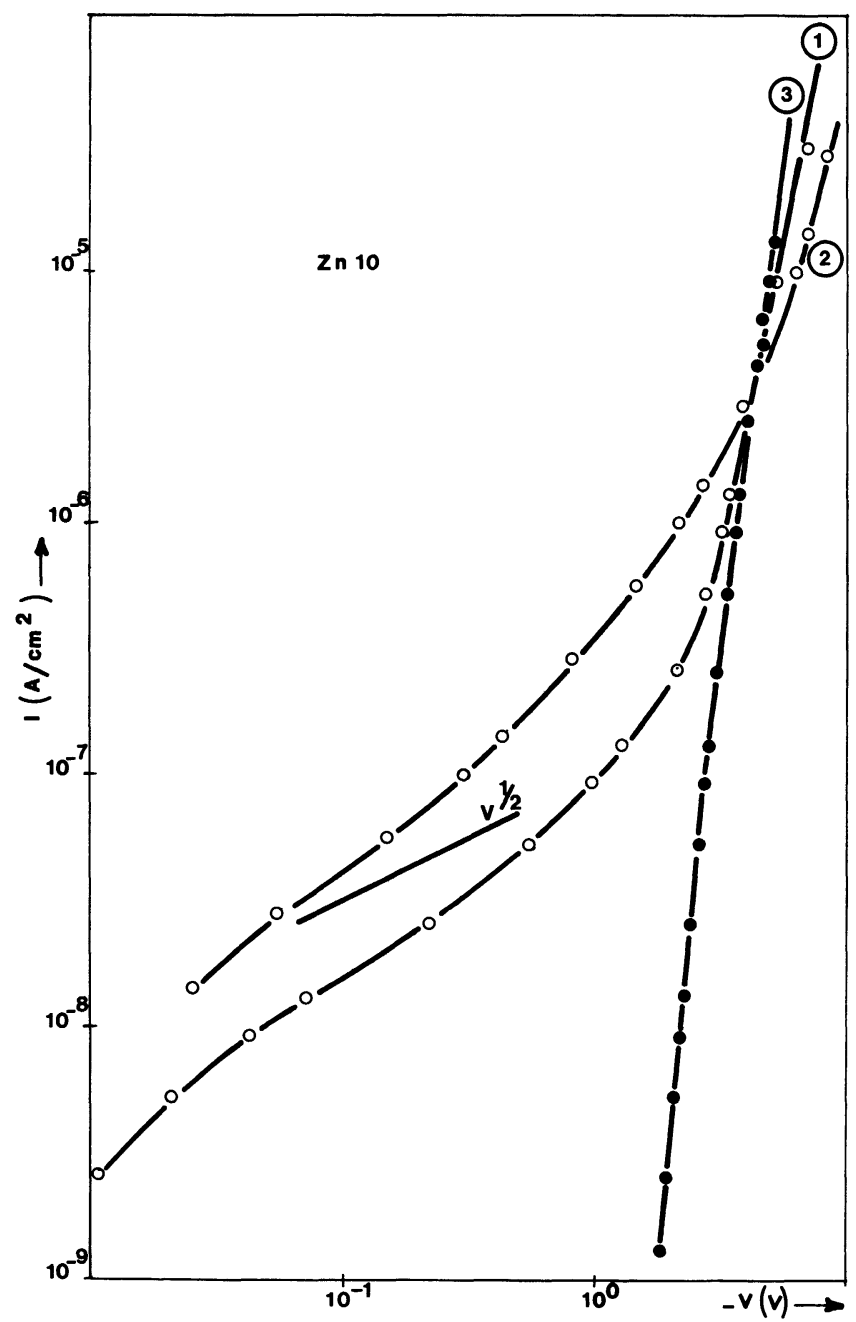

Fig. 11. $-300 \mathrm{~K}$ dark reverse $I-V$ characteristic of the Zn 10 diode : $1 . S=0.077 \mathrm{~cm}^{2} O$; $2 . S=0.0072 \mathrm{~cm}^{2} O$. $80 \mathrm{~K}$ dark reverse $I-V$ characteristic of the $\mathrm{Zn} 10$ diode : 3. $S=0.077 \mathrm{~cm}^{2}$ method. The only ITO spray deposition procedure results in simultaneous diode fabrication and antireflection coating deposition. Taking into account the reflection losses, the internal quantum efficiency can be estimated, it is near 1 between 0.35 and $0.92 \mu \mathrm{m}$. The $\eta_{\mathrm{q}}$ calculation in a buried homojunction will accounts for the experimental $\eta_{\mathrm{q}}$ spectrum [13].

The reverse current level is an important photodetector parameter. Figure 11 presents the reverse room temperature characteristics corresponding to two regions and two different surfaces of the $\mathrm{Zn} 10$ diode. The breakdown occurs near $-10 \mathrm{~V}$. The current density is not exactly the same for the two diodes but the discrepancy is more typical of a rather inhomogeneous structure than of a structure showing strong local leakages.

The $V^{1 / 2}$ law (generation-recombination law for strong reverse biases [16] is never obeyed). At $80 \mathrm{~K}$ an abrupt $I$ variation is observed for voltages as low as $-1 \mathrm{~V}$. For $-V<4 \mathrm{~V}, I_{80 \mathrm{~K}} \ll I_{300 \mathrm{~K}}$ then the detectivity threshold value at $80 \mathrm{~K}$ is smaller than at $300 \mathrm{~K}$; this photodetector would then be much more efficient at $80 \mathrm{~K}$ using an inverse bias of about $1 \mathrm{~V}$.

5.3 Temperature VARIATION OF PHOTOELECTRICAL PARAMETERS. - Figures $12 \mathrm{a}$ and $\mathrm{b}$ show the $I_{\text {sc }}$ and $V_{\text {oc }}$ variations versus temperature between 77 and $300 \mathrm{~K}$ for the $\mathrm{Zn} 26$ diode and between 300 and $533 \mathrm{~K}$ for the $\mathrm{Zn} 63$ diode. These figures show that the device can work at any temperature between 77 and $533 \mathrm{~K}$. The diodes show a remarkable stability : either cold or heat treated diode is reversible and keeps the same properties after thermal treatment.

At room temperature, $V_{\text {oc }}$ closely follows the classical relation

$$
\begin{aligned}
V_{\mathrm{oc}} & =\frac{n k T}{q} \operatorname{Ln} \frac{I_{\mathrm{ph}}}{I_{0}}, \quad I_{\mathrm{ph}}: \text { photoelectrical current } \\
I_{0} & =I_{00} \mathrm{e}^{-\Delta E / k T} \\
V_{\mathrm{oc}} & =\frac{n \Delta E}{q}-\frac{n k T}{q} \operatorname{Ln} \frac{I_{00}}{I_{\mathrm{ph}}} .
\end{aligned}
$$

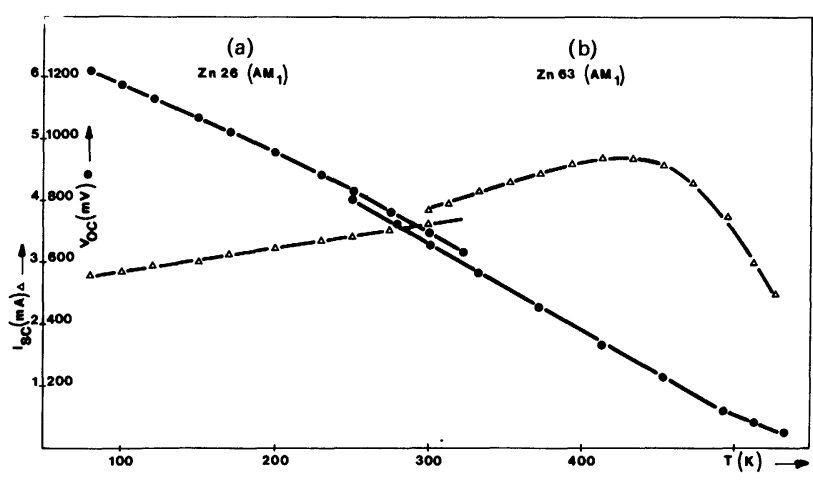

Fig. 12. - Temperature $I_{\mathrm{sc}}: \triangle$ and $V_{\mathrm{oc}}: \bullet$ variations : a) Low temperature range $77<T<300 \mathrm{~K}$, Zn 26 $\left(T_{\mathrm{sp}} 450{ }^{\circ} \mathrm{C} . C_{\mathrm{Sn}}: 1 \%\right.$ ). b) High temperature range $300<T<533 \mathrm{~K}, \mathrm{Zn} 63$ diode $\left(T_{\mathrm{sp}} 450^{\circ} \mathrm{C} . C_{\mathrm{Sn}}: 1 \%\right)$. 
If $\Delta E$ follows the gap temperature variation :

$$
E_{\mathrm{g}}=E_{\mathrm{g}_{0}}-\alpha T, \quad \alpha \sim 4 \times 10^{-4} \mathrm{eV} / \mathrm{K}
$$

in InP, the temperature variation of $V_{\mathrm{oc}}$ can be written

$$
\frac{\mathrm{d} V_{\mathrm{oc}}}{\mathrm{d} T}=-\frac{n}{q}\left(k \log \frac{I_{00}}{I_{\mathrm{ph}}}+\alpha\right) .
$$

The experimental $V_{\text {oc }}$ temperature coefficient observed on the $\mathrm{Zn} 26$ diode is $-2.7 \mathrm{mV} / \mathrm{K}$ whereas the calculated one is about $-3.4 \mathrm{mV} / \mathrm{K}$. This discrepancy can be due to the fact that at low temperature, the generation-recombination model is no longer valid and the apparent $I_{00}$ value is lower.

The $I_{\text {sc }}$ variation is weak and very similar to the observed one on $\mathrm{n}$ CdS/InP diodes [17], in sputtered ITO/InP diodes [18] or in GaAs diodes [19]. The increase of $I_{\text {sc }}$ with temperature due to the decrease of the InP gas and then to the window widening is negligible. The $I_{\mathrm{sc}}$ increase is generally attributed to an increase of the diffusion length with increasing temperature. The strong and reversible decrease of $I_{\text {sc }}$ for $T>475 \mathrm{~K}$ does not correspond to the intrinsic behaviour of $\operatorname{InP}$; it has also been observed in $\mathrm{CdS} / \mathrm{InP}$ diodes for $T>600 \mathrm{~K}$ [17].

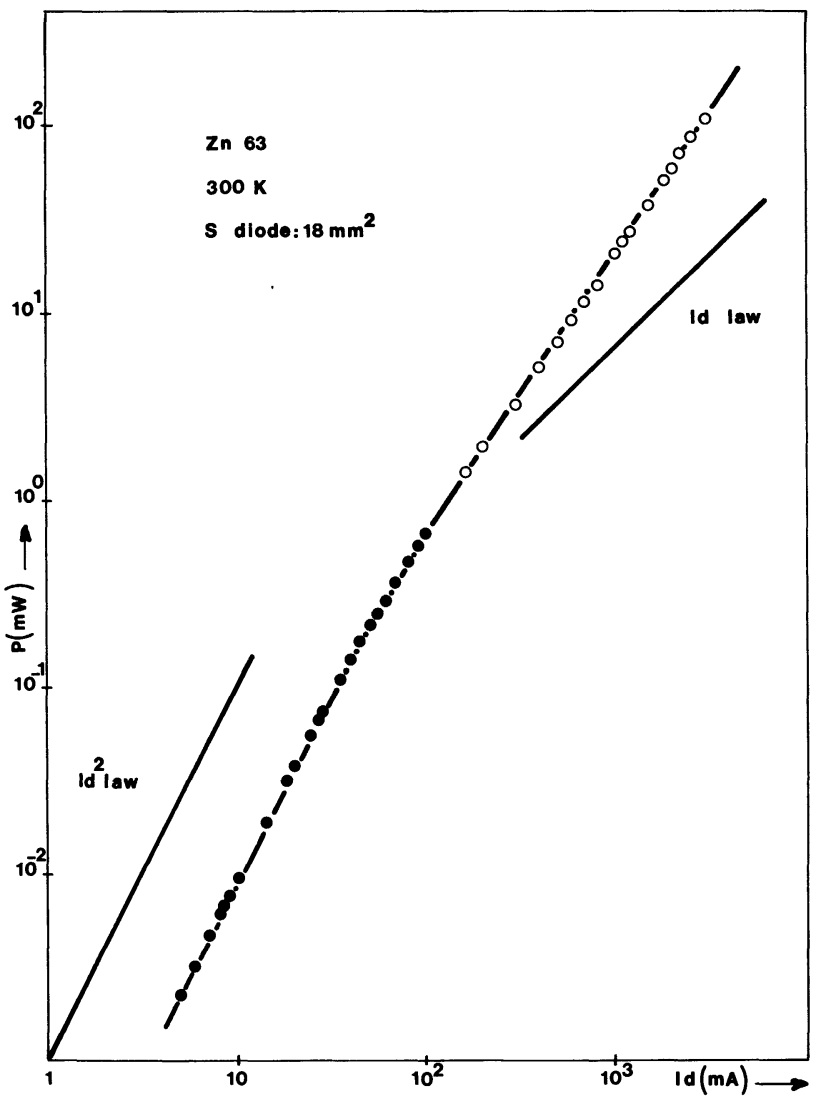

Fig. 13. - Emitted light power $P$ of $\mathrm{Zn} 63$ diode at $300 \mathrm{~K}$ as a function of the diode direct current $I_{\mathrm{d}}$. $\bullet$ direct current measurement; $O$ pulsed current measurement : pulse time : $500 \mu \mathrm{s}$, frequency : $12 \mathrm{~Hz}$. Diode surface : $18 \mathrm{~mm}^{2}$. Emitting surface : $17.3 \mathrm{~mm}^{2}$.

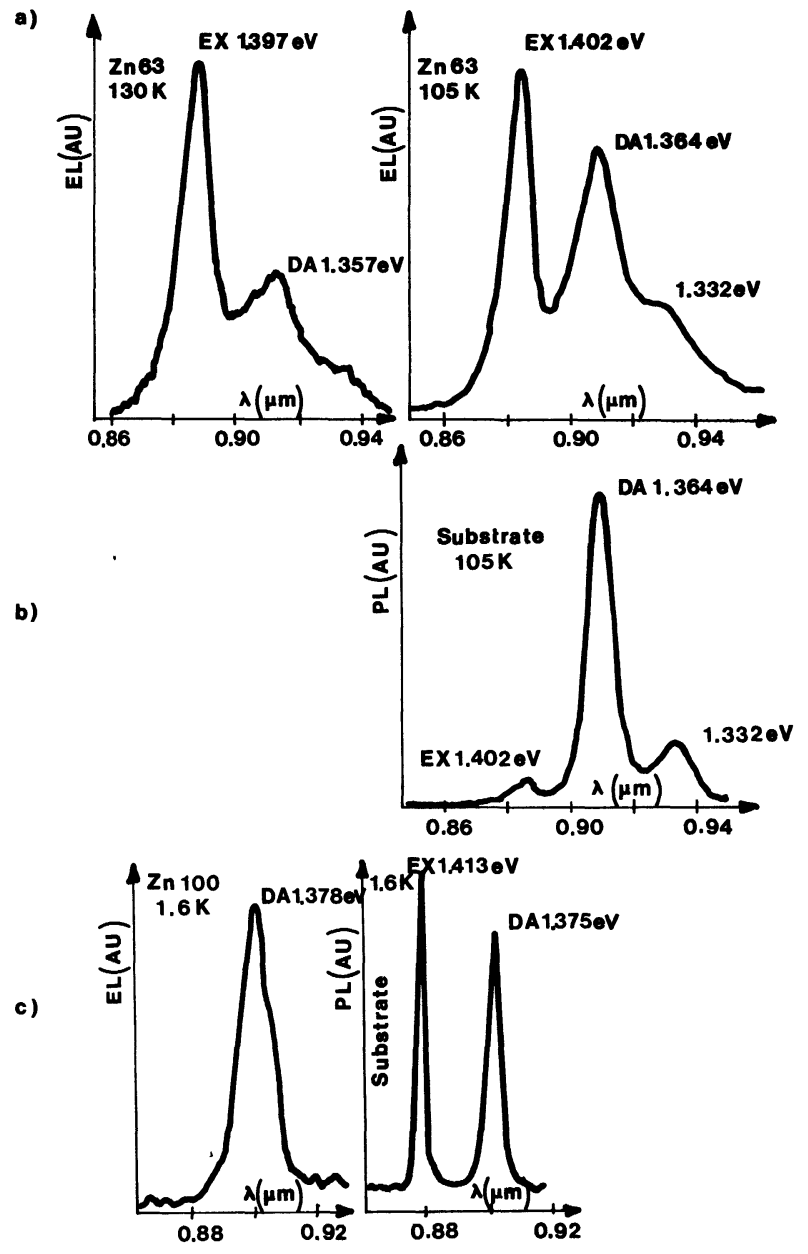

Fig. 14. - a) Electroluminescence spectra on $\mathrm{Zn} 63$ diode at $130 \mathrm{~K}$ and $105 \mathrm{~K}$ showing the bound excitonic (EX) recombination and the donor-acceptor (DA) recombination, $I_{\mathrm{d}}=100 \mathrm{~mA}$. b) Photoluminescence spectra on InP substrate at $T=105 \mathrm{~K}$. c) Photo and electroluminescence spectra at $1.6 \mathrm{~K}$ (EL on $\mathrm{Zn} 100$ diode, $\left.I_{\mathrm{d}}=80 \mathrm{~mA}\right)$.

6. Electroluminescent properties. - These diodes work as electroluminescent diodes between 1.6 and $300 \mathrm{~K}$.

At room temperature the emission peaks at $1.34 \mathrm{eV}$, it is $50 \mathrm{meV}$ width. The emitted light has been detected by a $\mathrm{Si}$ detector. The variation of the power of the emitted light as a function of the direct diode current $I_{\mathrm{d}}$ is shown in figure 13, it obeys an $I_{\mathrm{d}}^{2}$ law at low level $I_{\mathrm{d}}<100 \mathrm{~mA}$, then the variation becomes more smooth. Such types of emission laws were observed on GaAs diodes [20]. At low temperature, the electroluminescence (EL) spectrum is resolved into two peaks separated by about $40 \mathrm{meV}$. Figure $14 a$ shows that the maxima amplitude ratio of these peaks depends on temperature. The amplitudes of both peaks increase with decreasing temperature. The electroluminescence peaks occur at the same photon energies as photoluminescence (PL) peaks, however, figure $14 b$ shows that the relative amplitude of the low and high energy peaks is not the same. Figure $14 c$ compares the PL 
and $\mathrm{EL}$ of $\mathrm{Zn} 100$ diode at $1.6 \mathrm{~K}$. The comparison of our results with those published by Dean [21], white [22] and Tsai [10] allows to attribute the high energy peak to acceptor bound excitonic recombination (EX), the lower energy peak to donor-acceptor pair recombinations (DA), the $\mathrm{Zn}$ acceptor level being about $40 \mathrm{meV}$ distant from the valence band. The little lowest energy peak may be the phonon replica of the DA recombination peak.

7. Conclusion. - An efficient $\mathrm{n}$ ITO/p InP device, able to work as photodetector, solar cell and LED has been fabricated and characterized. The very simple fabrication method is based on the liquid phase hydrolysis (spray) method. It allows to realize simultaneously the diode fabrication and the antireflecting coating deposition. This type of device has been characterized. Interface investigation by EBIC profile measurement has shown that it was of a buried homojunction type. Ion probe analysis shows the presence $\mathrm{P}-\mathrm{O}$ bonds at the ITO-InP interface then a SIS structure behaviour may also participate to the device properties. Dark direct $I-V$ characteristics in the high temperature range $(213-323 \mathrm{~K})$ generally well agree with the generation recombination transport model in an homojunction; however when pure $\operatorname{In}_{2} \mathrm{O}_{3}$ is used or for diodes with a very thin ITO layer, tunnelling dominates transport.

These diodes are efficient solar cells, a $14 \%$ efficiency has been measured under AM1 illumination on a $18 \mathrm{~mm}^{2}$ diode. Used as a photodetector, the responsitivity of this device is $0.57 \mathrm{~A} / \mathrm{W}$ at $1.40 \mathrm{eV}$, the dark inverse current density is $8 \times 10^{-6} \mathrm{~A} / \mathrm{cm}^{2}$ at $-5 \mathrm{~V}$.

The study of the temperature variation of photoelectrical parameters like short circuit current $I_{\mathrm{sc}}$ and open circuit voltage $V_{\text {oc }}$ shows that the device can work between $77 \mathrm{~K}$ and $533 \mathrm{~K}$ without any degradation indication. Time responses have not yet been investigated.

Electroluminescence has been observed between 1.6 and $300 \mathrm{~K}$. Emitted light power of $0.67 \mathrm{~mW}$ has been measured at $300 \mathrm{~K}$ for a direct current of $100 \mathrm{~mA}$.

In its working wavelength range, this device can with difficulty compete with $\mathrm{Si}$ or GaAs diodes but it can be hoped that this simple technology might be applied to the realization of IR devices in the wavelength range of interest for optical telecommunications using for example GaAlSb or GaAlAsSb as substrates.

References

[1] Barrera, J. S., Archer, R. J., IEEE Trans. ED 22 (1975) 1023.

[2] Engelmann, R. W. H., Liech, C. A., IEEE Trans. ED 24 (1977) 1288.

[3] WadA, O., Majerfeld, A., Electron. Lett. 14 (1978) 125.

[4] Kamimura, K., Suzuki, T., Kunioba, A., J. Appl. Phys. 51 (9) (1980) 4905.

[5] Kamimura, K., Suzuki, T., Kunioba, A., Appl. Phys. Lett. 38 (4) (1981) 259.

[6] HokeleK, E., Robinson, G. Y., Solid State El. 24 (1981) 99.

[7] Shay, J. L., Wagner, S., Bettini, M., BachmanN, K. J., BUEHLER, E., IEEE Trans. ED 24 (1977) 483.

[8] SRee Harsha, K. S., Bachmann, K. J., Schmidt, P. H., Spencer, E. G., Thiel, F. J., Appl. Phys. Lett. 30 (1977) 645.

[9] Singh, R., Shewchun, J., J. Appl. Phys. 49 (1978) 4588.

[10] Tsai, M. J., Fahrenbruh, A., Bube, R. H., J. Appl. Phys. $51-5$ (1980) 2696.

[11] Turner, G. W., Fan, J. C. C., Hsieh, J. J., Appl. Phys. Lett. 37 (4) (1980) 400.
[12] Pommier, R., Gril, C., Marucchi, J., Thin Solid Films 77 (1981) 91.

[13] Gouskov, L., LuQuet, H., Esta, J., Gril, C., Solar Cells, 5-1 (1981) 51.

[14] Bachmann, K. J., Bitner, T., Thiel, F. A., SinClair, W. R., SchreIBer, H., Schmidt, P. H., Solar Energy Materials 1 (1979) 249.

[15] Sy Chiang, Pearson, G. L., J. Appl. Phys. 46-7 (1975) 2986.

[16] SAH, C. I., Noyce, R. N., Shockley, W., Proc. IRE (1957) 1228.

[17] Wagner, S., Shay, J. L., Bachmann, K. J., BueHLER, E., BetTINI, M., J. Crystal Growth 39 (1977) 128.

[18] TsaI, M. J., Ph D, Standord University, june 1979.

[19] Hovel, H., Semicond. and Semimetals, V. 2, Solar Cells (Academic Press, London) 1975, p. 166.

[10] Mayburg, S., Black, J., J. Appl. Phys. 34 (1963) 1521.

[21] Dean, P. J., Robbins, D. J., Bishop, S. G., Solid State Commun. 32 (1979) 379.

[22] White, A. M., Dean, P. J., DAy, B., J. Phys. C 7 (1974) 1400. 